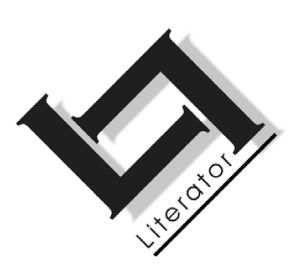

\title{
Omstrede kwessies en teksinterne korrektiewe in Skilpoppe van Barrie Hough
}

\author{
M.J. Fritz
}

Skool vir Tale:

Sentrum vir Akademiese \& Professionele Taalpraktyk

Potchefstroomkampus

Noordwes-Universiteit

POTCHEFSTROOM

E-pos: retha.fritz@nwu.ac.za

E.S. van der Westhuizen

Vakgroep Afrikaans \& Nederlands

Skool vir Tale

Potchefstroomkampus

Noordwes-Universiteit

POTCHEFSTROOM

E-pos: betsie.vanderwesthuizen@nwu.ac.za

\begin{abstract}
Controversial issues and text-internal correctives in Skilpoppe by Barrie Hough

This article focuses on the binary relations between controversial issues and text internal correctives by making use of examples from "Skilpoppe" (Babushka dolls) (2002) by Barrie Hough. The article starts with a discussion of controversial issues, including the four main categories, identified as violence, sexuality, politics and religion and continues briefly to the censorship as enacted before the Films and Publications Act, No. 65 of 1996 was passed. Thereafter the text-internal corrective, which is sometimes found to be an answer to controversial issues present in youth literature, is discussed and the binary relations between literary controversy and text-internal correctives are highlighted. The theory developed is then used in the analysis of controversial issues in "Skilpoppe".
\end{abstract}




\section{Opsomming}

\section{Omstrede kwessies en teksinterne korrektiewe in Skilpoppe van Barrie Hough}

Hierdie artikel fokus op die binêre verhoudings tussen omstrede kwessies en teksinterne korrektiewe in Afrikaanse jeugverhale, met spesifieke aandag aan die uitbeelding hiervan in "Skilpoppe" (2002) van Barrie Hough. Die artikel begin met 'n bespreking van omstrede kwessies, insluitende die vier hoofkategorieë, naamlik geweld, seksualiteit, politiek en godsdiens, waarna sensuur vóór die Wet op Publikasies en Vermaaklikhede, No. 64 van 1996 vlugtig aangeraak word. Daarna word die teksinterne korrektief wat dikwels in verhale gevind word as 'n antwoord op die omstrede kwessies wat uitgebeeld word, bespreek en die binêre verhouding tussen literêre omstredenheid en teksinterne korrektiewe beklemtoon. Die teorie wat ontwikkel is, word dan gebruik in die analise van omstrede kwessies in "Skilpoppe".

\section{Inleiding}

In die hedendaagse samelewing kry die meeste adolessente blootstelling aan 'n groot verskeidenheid media en die daarmee gepaardgaande idees en ideologieë. Dit het tot gevolg dat enorme hoeveelhede ongefilterde inligting met gemak, veral deur middel van die televisie, die internet en ander elektroniese media, asook in tydskrifte en ander publikasies bekom kan word. Dit is onafwendbaar dat daar ook inligting teenwoordig sal wees wat teenstrydig is met die waardes van die adolessent se ouers en dié van die gemeenskap waarin die adolessent opgevoed word. Weens omstandighede is leiding van volwassenes nie altyd geredelik vir die adolessent beskikbaar wanneer kontroversiële of omstrede inligting teëgekom word nie. In sulke situasies het die jeugdige dikwels twee opsies: hy/sy kan naamlik poog om 'n omstrede saak self te deurdink en tot 'n gevolgtrekking te kom, of hy/sy kan besluit om hom/haar te wend na menings in die portuurgroep.

Simpatieke volwassenes, soos onderwysers wat daagliks kontak met skoolleerders het, wil en kan dikwels 'n begeleidende rol speel. In 'n skoolomgewing (of in ander situasies) sal 'n volwassene hom kan wend tot jeugliteratuur as hulpmiddel, omdat dit 'n voor die hand liggende deel vorm van die skoolkurrikulum en 'n natuurlike aanknopingspunt vir gesprekke oor kwessies wat vir adolessente aktueel en relevant in hulle lewens is. Daarom is dit belangrik vir persone wat betrokke is by die opvoeding en leiding van die adolessent om te weet watter omstrede kwessies in resente jeugliteratuur voor- 
kom, aangesien dit dikwels 'n akkurate weerspieëling is van die tipe kwessies wat in sekere lewenstadia as problematies deur adolessente ervaar word. Die wyses waarop daar oplossings vir hierdie kwessies gebied word, bied op eksplisiete en implisiete wyses antwoorde op moontlike lewensvrae. Die bedoeling met hierdie artikel is nie om sekere waardes of 'n waardestelsel voor te hou as goed, al dan nie, maar om die teksinterne positiewe waardes, anders gestel - die teksinterne korrektiewe - wat in Barrie Hough se jeugverhaal Skilpoppe voorkom, aan te toon.

Inligting en kennis is een van die basiese behoeftes van die mens (Sutherland, 1977:13) en dit is daarom gewoonlik vanselfsprekend dat indien die adolessent met 'n problematiese kwessie gekonfronteer word, hy/sy soveel inligting as moontlik oor daardie kwessie sal wil bekom. Neigings in die moderne samelewing is dat die primêre bronne van inligting die portuurgroep en die internet sal wees, met sekere simpatieke volwassenes, soos onderwysers, gesinslede en ander, as sekondêre bronne. As gevolg van die beskikbaarheid van geweldige hoeveelhede inligting wat die afgelope dekade kubervinnig toeganklik gemaak word, heers daar enersyds 'n groter onsekerheid en andersyds 'n groter verdraagsaamheid ten opsigte van konflikterende standpunte. Dit gaan gepaard met die vervaging van tradisionele grense tussen sogenaamde absolute waardes soos dié van byvoorbeeld reg en verkeerd, of goed en kwaad. Hierdie vervaging kan ook as 'n uitvloeisel van die postmodernisme gesien word, aangesien die postmodernisme weier om aan enige enkele sisteem erkenning te gee as synde in die absoluut-beherende posisie wat byvoorbeeld goed en kwaad betref (Müller, 1992:397).

Hierdie tipe grensverskuiwings dui op veranderende waardestelsels, wat die taak van volwassenes bemoeilik wat in verskillende rolle en situasies aan adolessente leiding kan verskaf. Die inherente komplekse aard van omstrede kwessies vergemaklik beslis nie hierdie taak nie. Onsekerheid by volwassenes weens 'n gebrek aan ingeligtheid, opleiding en wysheid veroorsaak dat die adolessent dikwels op hom-/haarself aangewese is om te probeer sin maak van probleme, asook om vir hom-/haarself riglyne oor probleemsituasies neer te lê.

Dit is ook belangrik om in gedagte te hou dat hierdie proses nie net op adolessente van toepassing is nie. Om werklik groei te kan ervaar en bewustelik te lewe, word raamwerke gedurig teen die werklikheid getoets en soos wat relevante terugvoer verkry word, word hierdie raamwerke verander of aangepas soos nodig (Van der Walt, 1992:58). Ook volwassenes ondervind paradigmaskuiwe soos wat hulle kennis verbreed en hulle as mense groei. 
Daar is verskeie funksies wat deur die skep en vertel van verhale vervul word. Hierdie funksies is onder andere om inligting oor spesifieke lewenskwessies te verskaf (Du Plooy, 2001:22), asook om gebeurtenisse te toets aan die norme van 'n bepaalde gemeenskap/periode/tydvak (Elsbree aangehaal deur Du Plooy, 1993:57). Daar is gewoonlik 'n werklike lewensboodskap (message) wat deur die tema van die literêre werk ontsluit word en deur die leser ontgin kan word (Ryan, 1993:169). Sutherland (1977:25) meen dat boeke met probleemhanteringstemas nie net jeugdiges met dieselfde probleme kan help nie, maar ook ander lesers wat 'n raamwerk vir die simpatieke verstaan van die probleem moet ontwikkel. Hierdie inligtingsfunksie bepaal dat die adolessent hom/haar sal wend tot verhale wat oor dieselfde tema of omstrede kwessie handel as die een waaroor daar ondersoek ingestel word. Die soeke word natuurlik nie net tot literêre verhale beperk nie, maar sluit ook populêre media soos televisie en tydskrifte in (Barker, 1999:139).

Die leser kan, volgens Du Plooy (2001:22), deur identifisering met die karakters sy eie ervaringswêreld deur 'n soort rolspel vergroot. Dit beklemtoon die invloed van die hoofkarakter van die verhaal op die leser, veral ten opsigte van die maniere waarop die hoofkarakter die problematiese kwessie benader en die onderliggende standpunte wat die hoofkarakter ten opsigte van die kwessie handhaaf. Tekste met sulke karakters kan daarom 'n waardevolle hulpbron in die skoolomgewing wees, veral in gevalle waar die onderwyser(es) daartoe in staat is om die ervaring verder te medieer en so leiding aan sy/haar klas te bied. So 'n benadering is natuurlik nie beperk tot die skoolomgewing nie, maar kan net so effektief aangewend word deur ouers, bibliotekarisse, jeugleiers en andere.

\section{Omstrede kwessies}

Die woord omstrede word deur die HAT (2000:760) omskryf as sake waaroor daar verskillend geoordeel word. Op sigself is dit nie ' $n$ bevredigende definisie nie, aangesien daar vele sake is waaroor verskillend geoordeel kan word sonder om noodwendig omstrede te wees. Elemente wat nie in die bostaande definisie voorkom nie, is dié van emosie en konflik. 'n Saak waaroor verskillend geoordeel word, word slegs omstrede wanneer 'n sterk emosie gekoppel word aan konflikterende werklikheidsvisies wat betrokke is by die waardeoordeel.

Volgens Steenberg (1988:15) stel alle adolessente die een of ander tyd bewustelik of onbewustelik ondersoek in na lewensfilosofieë, waardesisteme en verset teen die samelewing. Vanselfsprekend sal 
hierdie soeke, dikwels tematies, ook met die representasie van omstrede kwessies as onderwerp, in jeugboeke voorkom. Dit is natuurlik en nodig ter voorbereiding op die eise wat die volwasse lewe aan die adolessent sal stel. Steenberg (1988:15) beklemtoon derhalwe die belangrike rol wat objektiwiteit tydens die uitbeelding van omstrede kwessies speel, om sodoende aan die adolessent die geleentheid te bied om self afleidings en gevolgtrekkings oor hierdie tipe sake te maak.

In resente Afrikaanse jeugliteratuur is daar talle voorbeelde van verhale waarin omstrede kwessies voorkom: Skilpoppe (Barrie Hough, 1998) gee die leser 'n onpartydige blik op die Christendom en ander religieë; !Sit, oom Paul (Johann de Waal, 1995) lewer kritiek op die geïnstitusionaliseerde religie en Daar's vis in die punch (Jackie Nagtegaal, 2002) vermeng die Christelike met die esoteriese. Die dinge van 'n kind (Marita van der Vyver, 2000) handel oor tienerswangerskap en ook die politieke situasie in die laat sewentigs; 'n Pot vol winter (Maretha Maartens, 1989) handel oor selfmoord asook voorhuwelikse seks; Die ongelooflike avonture van Hanna Hoekom (Marita van der Vyver, 2008) werk prominent met seksuele oriëntasie en Slinger-slinger (Francois Bloemhof, 1997) het dit oor buitehuwelikse/voorhuwelikse seks asook seksuele oriëntasie. Vaselinetjie (Anoeschka von Meck, 2004) werk onder andere met rassepolitiek en bendegeweld; so ook Spinnekopsomer (Maretha Maartens, 1992); Geraamtes dra nie klere nie (J.A.W. Vermeulen, 2000) handel oor die verhore van die Waarheids- en Versoeningskommissie en politieke geweld en Tippex dit uit (Anna-Marie Conradie, 2001) handel oor die gevolge van verkragting. Elkarien Fourie se simpatieke benadering tot die adolessent se behoefte om self ' $n$ verskeidenheid religieë, politieke oortuigings en lewenskwessies te oordink en daaroor standpunt in te neem, kom tot uitdrukking in Dans op die rand van 'n krans (2002). Laastens kan daar ook gedink word aan Breinbliksem (Fanie Viljoen, 2005) waarin geweld eksplisiet voorkom. Hierdie tekste is net enkele voorbeelde van die groot verskeidenheid jeugverhale in die Afrikaanse literatuur waarin omstrede kwessies voorkom. Duidelik kan daar meer onderwerpe en kombinasies van omstrede onderwerpe as slegs een omstrede kwessie in 'n teks voorkom.

'n Algemene samelewingsrespons op omstrede kwessies is dié van sensuur - nie net in volwasse literatuur nie, maar ook in jeugliteratuur. Volgens West (2004:680) word sensuur deur veral drie redes gemotiveer, naamlik: sensuur word toegepas op verhale met 'n inhoud wat strydig is met die geloof of dogma van 'n geïnstitusio- 
naliseerde religie; boeke word gesensureer omdat die inhoud daarvan bots met politieke ideale, sowel konserwatief as liberaal; volwassenes wat baie sterk oor 'n sekere saak voel, kan hulle ook tot sensuur wend.

In Suid-Afrika is sensuur tot 1996 deur twee wette beheer, naamlik die Wet op Binnelandse Sekuriteit 44 van 1950 en die Wet op Publikasies 42 van 1974 (Dugard, 1980:67; Van Rensburg, 1985:101). Met hierdie twee wette is gepoog om toegang tot erotiese/pornografiese tydskrifte, asook literêre werke wat religieus aanstoot kon gee en/of die regering se apartheidsbeleid bevraagteken het, te verbied (Dugard, 1980:67; Van Rensburg, 1985:111). Met die uitsondering van Stanley en die boikot (John Miles, 1980), is geen kinder- of jeugliteratuur egter al ooit in Suid-Afrika verban nie.

Omdat sensuurwette wêreldwyd hoofsaaklik oorweeg word volgens die kategorieë geweld, politiek, seksualiteit en religie, word omstrede kwessies in jeugliteratuur ook ten opsigte van hierdie vier kategorieë ondersoek, maar dan met 'n begrip van verhaalteoretiese uitgangspunte.

\subsection{Geweld}

Geweld is 'n belangrike kategorie in 'n ondersoek oor omstrede kwessies, aangesien elke mens 'n behoefte aan veiligheid en sekuriteit het - iets wat deur die voorkoms van geweld aangetas word. Daar is tans 'n tendens in die media (films, koerante, rekenaar-/tvspeletjies) om geweld so werklikheidsgetrou moontlik aan te bied. Tog is daar ook heelwat teenstand teen hierdie neiging en is daar wel pogings om sensuur toe te pas, veral in die vorm van ouderdomsbeperkings. Hierdie aksies spruit uit die besorgdheid dat blootstelling aan realistiese uitbeeldings van geweld die ontwikkelende adolessent kan beïnvloed om die gewelddadige voorbeeld na te volg. Dimensies van geweld sluit onder andere fisiese, emosionele en seksuele mishandeling in.

In jeugliteratuur kom daar dikwels, implisiet of eksplisiet, geweld voor. ' $n$ Voorbeeld hiervan is Leon Rousseau se Fritz Deelmanreeks (1956-1963). 'n Belangrike faktor wat betref die gewildheid van hierdie boeke, is die aksie- en daarom ook die geweldselement. ' $n$ Meer resente voorbeeld van eksplisiete geweld in ' $n$ jeugroman is dié in Breinbliksem (Viljoen). In 'n land waar voorvalle van geweldsmisdaad besonder hoog is, is dit verstaanbaar dat hierdie element na vore sal kom in die media en literatuur, insluitende jeugliteratuur. 


\subsection{Politiek}

In die breë het politiek te doen met die inwoners van 'n land se poging om sinvolle strukture vir regulering en administrasie vir die land te voorsien. Indien daar gedink word aan hoeveel verskillende gemeenskappe, kulture en ordes daar in 'n land kan voorkom, is dit verstaanbaar dat die ooreenkomste op 'n aanvaarde stel reguleringsprinsipes 'n omstrede kwessie kan wees. Die hele samelewing asook die kultuurprodukte van verskillende groepe word deur 'n land se politieke stelsel beïnvloed en daarom het politiek ook 'n sterk invloed op jeugliteratuur.

Die Suid-Afrikaanse geskiedenis is 'n bewys daarvan dat verskeie politieke eras 'n groot positiewe, maar dikwels ook negatiewe, invloed op Suid-Afrikaners gehad het. Die rimpeleffek daarvan word gewoonlik voortgedra na volgende generasies. Nie net die vorige politieke bedeling nie, maar ook debatteerbare aspekte van 'n nuwe politieke bedeling vind neerslag in die literatuur, ook in jeugliteratuur. 'n Voorbeeld hiervan is die wyse waarop die ou en die nuwe politieke bedelings vervleg is in tekste soos Geraamtes dra nie klere nie (Vermeulen).

\subsection{Seksualiteit}

Seksualiteit is 'n basiese aspek van die mens se bestaan, maar die uitlewing en die uitbeelding daarvan in die kunste, is dikwels in die spervuur. Norms aangaande seksualiteit kan drasties van kultuur tot kultuur en era tot era verskil. Vraagstukke rondom homoseksualiteit en prostitusie, asook die onderskeid tussen erotiek en pornografie is steeds internasionaal omstrede kwessies. Tans is reaksies nie so hewig hieroor soos in vorige eeue nie. Tot in die sewentigerjare van die twintigste eeu het hofsake tussen redakteurs van pornografiese tydskrifte en die staat groot opspraak gewek in die VSA en Brittanje.

Die ontwikkelende adolessent is dikwels nuuskierig oor aspekte van seksualiteit en "verbode" of "taboe-"onderwerpe en die media word dan uiteraard ondersoek waar moontlik. Weereens is die internet 'n gerieflike en toeganklike bron van "verbode" inligting. In die portuurgroep van die adolessent word dikwels geëksperimenteer met verskillende fasette rondom die uitleef van seksualiteit. Hierdie fassinasie kom in die media voor (dink maar aan die American Pie-films, 1999-2009) en ook in jeugliteratuur. In die Afrikaanse jeugliteratuur is daar heelwat tekste waaroor omstredenheid ontstaan het as gevolg van die seksualiteit daarin, waarvan ' $n$ Pot vol winter (Maartens) moontlik die baanbreker was en Slinger-slinger (Bloemhof) 'n 
hele nuwe betekenis gegee het aan die konsep van diverse seksuele verhoudings.

\subsection{Religie en godsdiens}

Religie en godsdiens (as die geloofsbeoefening van 'n religie) word soms as omstrede ervaar, aangesien lewensbeginsels, norme en waardes verskillend geïnterpreteer en uitgeleef word deur mense van verskillende religieë en godsdienste. Alhoewel die Suid-Afrikaanse grondwet vryheid van geloof verseker, kan dit 'n bron van konflik wees indien sekere dele van die samelewing dit as hulle roeping beskou om die samelewing teen sekere vorms van kunsbeoefening te beskerm, terwyl ander voel dat die effek van 'n ander se geloofsbeoefening inbreuk maak op hulle vryheid om self keuses te maak.

Adolessensie word gekarakteriseer deur 'n tydperk van soeke. Die adolessent is besig om sy eie identiteit te definieer en bevraagteken dus sekere vasgestelde gemeenskapsnorms, terwyl ander vorms ondersoek word. As deel van hierdie proses kan religie ook bevraagteken word, terwyl ander religieë ondersoek en getoets word. Alhoewel daar dikwels in jeugverhale slegs 'n klein komponent aan religie of geloof gewy word, werk dit deur na die hele verhaal. 'n Voorbeeld hiervan is die miniatuur-Bybeltjie (klein in die letterlike en figuurlike sin van die woord) in Dans op die rand van 'n krans (Fourie), waarteen sommige lesers besware sou kon hê indien hulle nie die verbande tussen die Christelike geloof en die Keltiese mitologie sou ondersoek of sou aanvaar nie. Nog 'n voorbeeld is dié van !Sit Oom Paul (De Waal) waar die hoofkarakter kennis maak met die Islam en hom teen die Christelike bande waarmee hy grootgeword het, verset.

\section{Die teksinterne korrektief}

Oor die nosie teksinterne korrektief as literêre verskynsel bestaan daar na die wete van die outeurs van hierdie artikel geen bronne nie. Die bedoeling met hierdie artikel is juis om 'n mening te stel oor teksinterne korrektiewe, sodat moontlike geïnteresseerdes dit sou kon gebruik en bydra tot die ontwikkeling van 'n volwaardige teorie en paradigma rondom hierdie verskynsel. Hierdie verskynsel kan talle moontlikhede in talle kontekste hê.

Alhoewel verbandhoudende literatuur rondom die teksinterne korrektief ook skaars is, sou daar begin kon word met 'n ontleding van die begrip teksinterne korrektief. Teksinterne verwys na dit wat in die 
teks gebeur, nie net op die bladsy nie, maar ook in die verhaal. Korrektief hou verband met korrek, korrigeer en korreksie. Wanneer 'n katalogussoektog vir die begrip korrektief gedoen word, toon die meerderheid resultate 'n verband met die strafregtelike korrektiewe stelsel. Teksinterne korrektiewe kan dus beskou word as verhaalmatige procédés waarmee negatiewe waardes ten opsigte van karakters se handeling, die gebeure, die ruimte en tydsaspekte binne in die verhaalwêreld herstel, omgekeer, verander of aangepas word om die eintlik bedoelde positiewe waardes na vore te laat kom en sigbaar te maak.

'n Teksinterne literêre korrektief kan nie op sy eie staan nie, maar is gebonde aan en staan altyd in verhouding tot die voorafgaande "niekorrekte". Teksintern of verhaalgebonde beteken dat die nie-korrekte gewoonlik eers in die verhaal gestel moet word, sodat die kommentaar wat deur korrektief gelewer word binne 'n ondersteunende raamwerk voorgehou word. Net soos een teenoorgestelde nie sonder die ander kan bestaan nie, benodig die teksinterne korrektief sy teksinterne teenoorgestelde om in konteks verstaan te kan word.

Teksinterne korrektiewe is belangrike wyses waarop daar verhaalmatig oplossings vir omstrede kwessies gebied word. In 'n ondersoek deur Van der Westhuizen (1990) na die voorkoms van kontroversiële of omstrede kwessies in films en die Afrikaanse romankuns, is na aanleiding van Suid-Afrikaanse sensuurwette in die twintigste eeu, vier kategorieë omstrede kwessies in literêre tekste geïdentifiseer, naamlik geweld, politiek, seksualiteit en godsdiens - soos wat dit verband hou met teksinterne korrektiewe gebaseer op die verhaalaspekte van verteller en vertelstrategie, fokalisator, karakters, gebeure, ruimte en tyd. In 'n verdere ondersoek deur Fritz (2007:9091 ) is aangetoon dat teksinterne korrektiewe gewoonlik ook verband hou met rolmodelle, reaksie van ander, fisiese en ook emosionele gevolge. Wanneer die teorie in teksanalises toegepas word, kan 'n geïntegreerde benadering as beskrywende metode gebruik word.

\subsection{Die teksinterne korrektief en narratiewe aspekte}

Die belangrikste rol van die verteller en verteltegniek in die skep van teksinterne korrektiewe is moontlik die doel waarmee die verteller die storie vertel en ook waarom die verteller juis die spesifieke verhaal gekies het om te vertel. Die ooglopendste antwoord op die vraag waarom die verteller die verteltegniek op sekere maniere sal gebruik sodat die negatiewe uitgelig en die positiewe gesuggereer kan word, is dat hierdie verhaal waarskynlik iets toelig wat 'n sterk indruk op die reële outeur gemaak of 'n sterk impak op sy/haar lewe 
gehad het - óf die outeur se eie lewe óf op die lewe van iemand wat hy/sy waargeneem het wat baie naby aan hom/haar was. Daar is 'n sekere tema of abstrakte lewensinsig wat die verteller, as gedelegeerde van die outeur, deur middel van die verhaal wil oordra. Die verteller "leef" slegs as iets wat uit die outeur voortvloei en is ook gebonde aan die outeur. Enige boodskap of vertelling wat as sodanig deur die verteller oorgedra word, geskied deur die wil en met toestemming van die outeur. Daardie boodskap wat oorgedra word, staan as deel van die sentrale tema(s). Die verteltegniek bemiddel die oordrag van die ervaring van die gebeure en daardeur kan die karakters of implisiete verteller ook standpunt inneem ten opsigte van sake in die verhaal. In die lig hiervan sal die toon waarmee die verteller sekere gebeure vertel belangrik wees, aangesien die verteller deur sy toon afkeur, goedkeuring of neutraliteit kan oordra.

Die keuse van fokalisasie kan vanuit 'n teksinterne korrektiewe aanslag ' $n$ baie belangrike faktor wees. Die fokalisator bepaal die atmosfeer, asook watter betekenis daar aan gebeurtenisse geheg word. Dit is dus belangrik om die die rol van die fokalisator, die karakter en die gebeure te verreken in die verstaan van korrektiewe.

Die tipe karakterisering wat in die verhaal voorkom, is instrumenteel in die skep van teksinterne korrektiewe. Die twee tipes wat hulle waarskynlik die meeste leen tot die opstel van die teksinterne korrektief is die ongure, negatiewe karakter en ook die karakter wat deur 'n swakheid of fout betrokke raak. 'n Ongure karakter kan beskou word as 'n karakter wat voortdurend met opset moeilikheid veroorsaak en ook aanhoudend poog om ander karakters hierby te betrek. Soms is die motief persoonlike gewin, ander kere bloot omdat die geleentheid om moeilikheid te skep daar is. 'n Ander soort karakter wat 'n baie waardevolle funksie in 'n korrektief het, is dié van die rolmodel - sekere karakters wat dien as die norm vir wenslike of aanvaarbare optrede. Die reaksies van karakters op sekere gebeure en hulle opinies oor sekere sake kan ook 'n waardevolle rigtingwyser vir die leser wees. Reaksies wat karakters teenoor omstrede/problematiese kwessies toon, kan positief of negatief wees. Die uitbeelding van die emosionele gevolge wat sekere aksies inhou, kan ook as 'n waarskuwingsmeganisme dien, aangesien dit dikwels emosionele gevolge is wat die grootste tol eis. Karakters kan fisies beseer word, maar die karakter se emosionele toestand bepaal hoe vinnig daardie besering verwerk en oorkom word. 'n Emosionele knou neem egter dikwels veel langer om te verwerk en oorkom te word as 'n fisiese besering. 
Geen verhaal kan sonder gebeure bestaan nie en teksinterne korrektiewe in verhale kan nog minder sonder gebeure volvoer word. 'n Metode om teksinterne korrektiewe deur middel van gebeure te klassifiseer, sal ten eerste die identifisering van omstrede kwessies en probleemsituasies wees. Daarna kan die loop van die situasie rondom die kwessie waargeneem en die uiteindelike gevolg aangeteken en geëvalueer word. Gebeure is ook 'n noodwendige ondersoekpunt vir die verkenning van die fisiese gevolge wat deur sekere handelings van karakters ontketen word.

Verder kan die ruimte bydra tot die skep van interne korrektiewe. Die leser kan hom-/haarself afvra watter tipe ruimtes hulleself tot problematiese situasies leen. Ruimte kan ook as positiewe versterking dien, waar positiewe handelings en reaksies ontstaan of na positiewe en versterkende ruimtes lei.

Ook die tydsbeelding kan insig bied in die skep en verstaan van korrektiewe. Daar is sekere tye wat hulself tot die oplewing van omstrede kwessies leen. Diefstal en bakleiery in dronkenskap, is byvoorbeeld oor die algemeen meer geneig om in die aand of vroeë oggendure plaas te vind. Tyd kan op 'n spesifieke era of politieke atmosfeer dui en die tydsverloop vanaf die begin tot die totstandkoming van 'n teksinterne korrektief, kan ook ondersoek word. Die graad van omstredenheid kan direk gekoppel word aan die tyd wat dit neem om tot 'n oplossing te kom - ernstiger sake is geneig om langer te neem om uit te sorteer.

\subsection{Toepassing: teksinterne korrektiewe in Skilpoppe (Barrie Hough)}

Reeds in die heel eerste resensies oor Skilpoppe is op omstredenhede in hierdie jeugverhaal gewys. Marina le Roux (1998:16) vestig die aandag op "die meesleurende, soms skokkende gebeure". Stephanie Nieuwoudt (1998:5) lê klem op die outeursintensie. Sy beklemtoon Hough se poging om met hierdie verhaal die aandag op dwelmgebruik te vestig, maar ook om deur die verhaal nuwe temas, nuwe perspektiewe en heling te bring, en haal hom soos volg aan:

Wanneer ek by skole met tieners gaan praat, vertel die kinders my van hulle probleme. Die dwelm crack is op die oomblik 'n groot probleem in die tienerkultuur. Dis deel van hulle lewe. Ek hoop om deur die boek te wys op die verskriklike gevare wat die dwelm inhou. '[...] En die gay-tema?' Mense kom deesdae al hoe vroeër uit die kas en hulle tydgenote aanvaar dit. Ek dink 
gay-wees moet ook in jeugboeke aangeroer word. [...] Ek hou daarvan om oor healing prosesse te skryf. (Nieuwoudt, 1998:5.)

Skilpoppe handel oor 'n gesin en die verskillende wyses waarop hulle geraak word deur die selfmoord van Sebast, die oudste kind in die gesin. Sebast is ' $n$ depressielyer en pleeg selfmoord na 'n tydperk van konflik tussen hom en sy pa oor sy homoseksuele verhouding met Ching-kung, 'n Suid-Afrikaner van Chinese herkoms. Na Sebast se selfmoord gaan sy ouers, Marius en Helena, vir 'n tydperk oorsee. Elise en Anna, Sebast se twee susters, bly agter saam met Florence, die huishulp, en Melina, die winkelassistent. Gedurende hierdie tydperk moet Anna oefen vir 'n opvoering van Romeo and Juliet, waarin sy die hoofrol vertolk. Intussen raak Elise, as gevolg van haar verhouding met Julian, al hoe meer betrokke by dwelmgebruik. Haar afhanklikheid word vererger deur die aard van haar werk, asook die emosionele gevolge van Sebast se selfmoord.

Alhoewel dit eers later in die verhaal toegelig word, is die selfmoord van Sebast die spilpunt van hierdie jeugverhaal. Voor dit is sy verhouding met Ching-kung (dubbel omstrede as gevolg van homoseksualiteit en ras), en stram verhouding met sy pa van belang. $\mathrm{Na}$ sy selfmoord onttrek die ouers hulleself van die gesin en kom Elise se verhouding met Julian en dwelmmisbruik na vore, wat uiteindelik lei tot 'n konfrontasie tussen Ching-kung en Julian. Dit is hierdie ses sentrale momente of omstrede kwessies wat vervolgens - met inagneming van die verhaalaspekte en die vier hoofkategorieë vir omstredenheid - geïntegreerd beredeneer word. Die omstrede kwessies word telkens eers ondersoek, waarna die teksinterne korrektief bespreek word.

\subsubsection{Sebast se verhouding met Ching-kung}

Sebast se verhouding met Ching-kung is in vele opsigte omstrede, aangesien dit verwys na homoseksualiteit, asook na rasseverskille wat verband hou met kulturele en religieuse verskille.

In al hierdie kwessies is dit veral die karakterisering van Anna, wat ook die ek-verteller is, wat bydra tot die teksinterne korrektief. Kulturele, religieuse en lewensbeskoulike kwessies word aangeraak wanneer Anna die wens uitspreek dat hulle, soos Ching-kung-hulle, 'n gesinsaltaar met wierookstokkies kon hê en hulle pa vanuit 'n Christelike oogpunt negatief daarop gereageer het. Sy herleef weer die herinnering toe hulle pa, in haar woorde, "amper 'n koronêr ge- 
skiet het oor die ding tussen Sebast en Ching-kung; 'Hy's 'n heiden, dié geel vriend van jou!' het Pa geskel." (p. 18).1 Na Sebast se dood is Anna steeds baie na aan Ching-kung en deur haar verhouding met hom leer die leser hom ook beter ken. Hy word uitgebeeld as 'n liefdevolle karakter met integriteit, maar wat ook in ' $n$ mate aan depressie ly. Dit kom ook na vore hoe baie hy Sebast mis. Wanneer Anna in Ching-kung se kamer met hom sit en gesels (hoofstuk 6 Musiek), praat hulle onder andere oor Sebast wat geneig was om tydens skemer depressief te raak. Tydens die gesprek kom die volgende gedagte by haar op: "Ek kan verstaan dat my broer lief was vir hom. Die gentleness straal so uit hom uit." (p. 45.) Simpatieke verstaan is soms iets wat ontbreek wanneer omstrede kwessies aangeraak word en hier bied die jeugverhaal 'n implisiete korrektief daarop. Uiteindelik is die versoening en vrede tussen die Meyers se pa en Ching-kung deel van die teksinterne korrektief wanneer Marius Meyer groter insig en aanvaarding van politieke, rasse-, kulturele en godsdienstige verskille tussen mense toon.

Ten opsigte van die rassekwessie is daar 'n verdere geval van teksinterne korrektiewe - Anna se vriendskap met Thoko. Hierdie vriendskap staan selfstandig in die verhaal, maar verleen ook resonansie en dimensie aan die rasseverhoudingskwessie tussen Sebast en Ching-kung. Anna en Thoko word vriende tydens hulle werk aan die toneelstuk van Romeo en Juliet. Thoko het grootgeword en bly steeds in die townships en verteenwoordig 'n hele wêreld en lewenswyse waaraan Anna nog nooit blootgestel is nie. Dit gee Anna ook baie stof tot nadenke, soos toe sy na 'n gesprek met Thoko oor taxigeweld in die klas sit en dink: "Ek dink aan Thoko se oom. Dood toe hy jonger was as wat ek nou is." (p. 42.) Deur Thoko leer Anna nog iets oor die samelewing waarvan sy deel is en so word haar ervaringswêreld verbreed.

\subsubsection{Sebast se verhouding met sy pa}

Wanneer die verhaal begin, is Sebast reeds dood, maar deur middel van die talle terugskouings word dit algaande duidelik dat Sebast 'n stormagtige verhouding met sy pa gehad het. Dit is veroorsaak deur hulle uiteenlopende lewens- en werklikheidsvisies. Marius (Sebast se pa) is 'n man wat hou van jag, en wat "kommuniste haat" (p. 9) en rassistiese vooroordele het. Sebast is homoseksueel en 'n vegetariër wat Green Peace ondersteun. Na een van hulle vele argumen-

1 Bronverwysings wat net 'n bladsynommer bevat, verwys na Hough (2002). 
te storm Sebast uit die huis uit terwyl Marius agter hom aansnou: "Seker op pad na sy geel vriend toe, geel en groen pas mos bymekaar." (p. 73.)

Aan die einde van die verhaal gaan haal Ching-kung en Anna haar ouers op die lughawe. Dit verras Marius, en Helena moet eers met hom praat voor hy loop na waar Anna en Ching-kung staan en wag (p. 89). Marius gaan selfs so ver om te weier om saam met Chingkung in 'n motor te klim: "Is ons op jóú aangewese vir vervoer terug huis toe? Ek kry liewer 'n taxi." (p. 90.) Hierdie houding vorm 'n sterk teenstelling met die gedaanteverwisseling wat hy teen die einde van die verhaal openbaar. Aan die einde van die verhaal gesels Marius en Ching-kung land en sand oor Koi en tydens die aandete bedank Ching-kung selfs vir Marius in Sjinees (p. 104-105). Uit hierdie ommekeer word die korrektief duidelik: waar Marius eers heeltemal teen Ching-kung gekant was, het sy houding nou verander en hy gee homself die geleentheid om Ching-kung beter te leer ken.

\subsubsection{Sebast se selfmoord}

Sebast word uitgebeeld as iemand wat aan depressie ly, wat vererger is deur die feit dat hy nie deur sy pa aanvaar is nie. Die uiteinde hiervan is 'n gru-selfmoord (p. 98-99). Anna was die eerste persoon om daarop af te kom in hulle pa se studeerkamer. Alhoewel die hele verhaal rondom hierdie selfmoord wentel, word die detail daarvan deur middel van die uitsteltegniek tot aan die verhaaleinde teruggehou om spanning in die verhaal op te bou. In 'n besonder treffende oorheenprojektering, byna filmiese superponering, van die laaste toneel in Romeo en Juliet met die toneel wanneer Anna afkom op die sterwende Sebast, word die ironie van fatale misverstande en wanverhoudings in individue, gesinne en gemeenskappe se lewens uitgehef.

Die reaksie van Sebast se geliefdes op sy selfmoord funksioneer as teksinterne korrektiewe in die verhaal. Die selfmoorddaad het 'n geweldige emosionele invloed op sy gesin, waardeur die wyer implikasies van die daad uitgebeeld word. Vir die leser is dit dus duidelik dat die gevolge van selfmoord nie net beperk is tot die persoon wat selfmoord pleeg nie. Dit strek verder deurdat dit die gesin en ook die persoon se vriendekring raak. Sebast se selfmoord dompel sy hele gesin in rou en lank na die gebeurtenis kan die gevolge nog gesien word. Sy ouers gaan selfs op reis in die buiteland om van die skok te probeer herstel. Elise ontwikkel 'n ernstige afhanklikheid aan Julian sowel as aan dwelms. Anna ervaar depressie en onderdruk haar herinnerings aan die dag wat sy Sebast gevind het. Ching-kung 
ervaar ook depressie. Al die karakters se ervarings dui op die ernstige emosionele gevolge wat die selfmoord op die gesinstruktuur en die individue daarbinne gehad het.

Indien Sebast se sterwe geen verandering gebring het nie, sou die verhaal, wat sy selfmoord betref, nie 'n teksinterne korrektief gehad het nie. Sonder om selfmoord in 'n positiewe lig te probeer stel, dra die uiteindelike positiewe veranderings in die interpersoonlike verhoudings tussen die opponerende karakters op ironiese wyse by tot die teksinterne korrektief. Die ironie is daarin geleë dat 'n karakter eers sy lewe verloor het voordat daar beter begrip tussen medekarakters met verskillende lewensvisies kon begin ontwikkel.

\subsubsection{Afwesige ouers}

Na Sebast se selfmoord vertrek Anna se ouers oorsee, waarskynlik om te probeer ontvlug aan die emosionele gevolge van die gebeure. Anna en Elise word op hulle eie agtergelaat met die verstandhouding dat hulle veronderstel is om dr. Snyman (die psigiater) gereeld te sien. Sowel Anna as Elise hou egter op om hulle afsprake met hom na te kom. Dit is nie die enigste keer dat die ouers afwesig is nie - Sebast het sy ma al vroeër as afwesig ervaar en Anna ook. Dit word vir die leser duidelik wanneer Helena haar sogenaamde "yskoningin" uithaal (p. 10) en ook wanneer Anna laatnag haar ouers se kamer besoek nadat hulle weg is. Helena se kamer word beskryf as uiters netjies en perfek (p. 38-39), wat ironies is, omdat juis dit Anna vervreemd laat voel. In die kamer sê Anna hardop: "Kon ma nie net 'n paar hare gelos het, 'n bietjie poeier gemors het nie? Net vir mý?" (p. 39.) Die talle argumente tussen Sebast en Marius het ook ongetwyfeld vervreemding tussen hulle veroorsaak.

Die afwesige ouers word gekontrasteer met die huishulp, Florence. Sy is altyd daar wanneer sy nodig is en haar teenwoordigheid is ' $n$ gegewe dwarsdeur die verhaal - al is sy nie fisies op die toneel nie. Wanneer Anna tydens haar voorbereiding op Romeo and Juliet karakters koppel aan kamers en mense, word die "nurse", die mees simpatieke en "grootmaakma" van Juliet, dadelik aan Florence gekoppel. Florence bring kos en kloek toe Anna en Elise seerkry (p. 32), Florence is teenwoordig toe die polisie die inbraak in die winkel ondersoek (p. 54), Florence "hau" en "Modimo" en dra koffie aan die aand toe Julian en Ching-kung slaags raak (p. 71), Florence maak die volgende oggend vir Anna ontbyt (p. 76) en Florence stuur Ching-kung om Anna aan ete te herinner toe Marcel vir haar kom kuier (p. 82). Alhoewel Florence nie 'n ouer in die gesin is nie, blyk dit dat sy wel die rol van ouer ingeneem het in die afwesigheid van 
die werklike ouers. Alhoewel die afwesigheid van ouers gewoonlik nie gesien word as emosionele geweld nie, is emosionele deprivasie wel 'n omstrede kwessie in die drie kinders in hierdie gesin se lewens. Wanneer die ouers terug is van hulle oorsese reis, eindig die verhaal met hoopvolle gebeure vir 'n nuwe begin in die pa se houding teenoor Ching-kung en die gesin se verstaan en vind van mekaar.

Hierby sluit ook die simboliek aan van veelvuldigheid en eenheid in die verhaaltitel, wat verwys na die Baboesjkapoppe wat Anna se pa vir haar van Moskou af gebring het (Van der Westhuizen, 2005:276). Alhoewel Baboesjkapoppe uit 'n stel eenderse poppe bestaan, word dit tradisioneel uit een stuk hout gesny wat die eenheid en geïntegreerdheid van die verskeidenheid selwe binne een persoon simboliseer. Behalwe dat die poppe in hierdie verhaal die verskeidenheid selwe of verskeidenheid fasette van dieselfde persoon kan simboliseer, kan dit ook op psigologiese integrasie en heelwording dui. Dit is betekenisvol dat Anna se pa vir haar die poppe as geskenk bring, maar dat hy self ook uiteindelik die een is wat heelwording ervaar. Sý veranderende houding word uiteindelik een van die belangrikste teksinterne korrektiewe in die verhaal, omdat hulle weer as gesin relatief gelukkig saam om 'n tafel is - met Ching-kung as gas, vir die eerste keer. Die helingsproses is egter nie afgehandel nie; die suggestie in die oop einde van die verhaal is dat die proses voortgaan.

\subsubsection{Elise se verhouding met Julian}

Elise begin onder die invloed van Julian, die "rowwe diamant", aldus Marius, dwelms gebruik, wat lei tot hallusinasies en vervolgingsvrees (p. 55). Die verhouding tussen Julian en Elise blyk ook seksueel te wees, na aanleiding van die erotiese foto's wat Anna in Elise se kamer vind (p. 79). Uiteindelik word Elise beseer in die konfrontasie tussen Julian en Ching-kung (p. 70). Seksualiteit en geweld is dus deel van die omstrede kwessies in die verhaal.

Die aard van Elise se verhouding met Julian word gekontrasteer met Anna se ontluikende verhouding met Marcel. Waar Elise en Julian se verhouding gebaseer is op emosionele afhanklikheid en dwelmgebruik, is Anna se verhouding met Marcel gegrond op verliefdheid, teerheid, kameraadskap en die behoefte aan 'n eerlike uitruil van gevoelens sonder die vrees vir verwerping. Wanneer Anna vir Elise in die rehabilitasiekliniek gaan kuier, erken Elise dat sy nie weer kontak met Julian sal kan maak nie, aangesien hy deel is van die verslawing (p. 104). Aan die ander kant is Anna se ervarings met Marcel net goed. Dit kom veral na vore wanneer hy vir haar kom 
kuier en hulle natuurlik in mekaar se geselskap kan wees (p. 82-85). Aan die einde van die aand soen hulle "lank en diep" (p. 85), wat op die begin van 'n nuwe soort verhouding tussen hulle dui.

\subsubsection{Konfrontasie tussen Ching-kung en Julian}

Die konfrontasie tussen Ching-kung en Julian vind een aand plaas nadat Elise Anna alleen by die huis gelos het (p. 69-79). Anna het Ching-kung gebel, aangesien sy bang was en hy het na haar toe gekom. Toe Julian uiteindelik vir Elise kom aflaai, was hulle albei onder die invloed van dwelms en dit het veroorsaak dat hy in Chingkung se motor vasry. 'n Konfrontasie waarin Elise beseer word, volg tussen Ching-kung en Julian.

Daar kan twee teksinterne korrektiewe aan hierdie situasie gekoppel word, naamlik Elise se besering en die strafregtelike vervolging van Julian. Elise het 'n duur les geleer deur haarself toe te laat om in hierdie destruktiewe verhouding verstrengel te raak. Sy het geweet dat Julian nie goed vir haar is nie, en tog was sy in so 'n mate afhanklik van hom en die dwelms wat hy voorsien het, dat sy hom nie kon los nie. Gedurende die konfrontasie word Julian se skadelike invloed op haar fisies gemanifesteer deurdat sy bewustelik tussen hom en Ching-kung inbeweeg en hy haar raaksny met sy mes. Sy sal altyd daardie litteken hê om haar aan hierdie gebeure te herinner. Die tweede interne korrektief word bewerkstellig deur Julian se inhegtenisneming. Dat hy 'n sekuriteitswag is, dra op 'n ironiese wyse by tot die korrektief. As sekuriteitswag is hy eintlik veronderstel om die ander te beskerm, en nie 'n negatiewe invloed op hulle lewens te hê nie. Elise sal later teen hom moet getuig en alhoewel sy hoop dat hy sal loskom (p. 104), is dit meer waarskynlik dat hy vir 'n tydperk tronkstraf sal moet uitdien. Dit sal ook beteken dat hy nie sy werk as sekuriteitswag sal kan behou nie.

\section{Samevattende gevolgtrekkings}

Die intensie van die reële outeur, Hough (Nieuwoudt, 1998:5), naamlik om in Skilpoppe enersyds van probleme en gevare, maar andersyds ook van 'n helingsproses te vertel, is deel van tweeledigheid as ' $n$ belangrike struktureringsprinsiepe in hierdie verhaal (Van der Westhuizen, 2005:276). Die aard van teksinterne korrektiewe gaan juis oor die tweeledigheid van binêre opposisies, omdat die negatiewe waardes in 'n verhaal soos Skilpoppe deur die eksplisiete beelding of implisiete suggestie van positiewe waardes omgekeer word. 
Dit is vanselfsprekend dat die adolessent in enige gemeenskap een of ander tyd met omstredenheid in aanraking sal kom. Dit is iets waaroor volwassenes in die adolessent se leefwêreld min beheer het, maar tog 'n sterk invloed kan uitoefen en daarom is dit baie belangrik om geleenthede en middels te benut waarin en waarmee die adolessent bereik kan word.

Een benadering kan wees om die adolessent in 'n beheerde omgewing aan omstredenheid in verwerkte of getransformeerde vorm bloot te stel - soos jeugliteratuur - waar daar ook bevoegde volwassenes teenwoordig is om leiding oor lewensvraagstukke, onder andere oor omstredenheid, te kan verskaf. Die adolessent kan dan gelei word deur die proses van die geleidelike uitbou van 'n interpretasieraamwerk waarmee vraagstukke benader kan word. Hierdie werkswyse rus die adolessent toe met kennis om, wanneer hy/sy op sy/haar eie met nuwe omstrede inligting gekonfronteer word, daartoe in staat te wees om sin uit die inligting te maak, asook om die inligting gepas in die situasie waarin dit na vore gekom het, te kan hanteer. Dit is hier waar kennis van teksinterne korrektiewe in jeugverhale waarin omstrede kwessies aangeraak word, 'n subtiele of eksplisiete rol kan speel in die vorm van begeleide groepsbesprekings (afhangende van die konteks) rondom relevante omstrede kwessies.

Omstredenheid kan beskou word as 'n onvermydelike deel van die uitwisseling van idees in 'n samelewing. Nuwe idees en invloede is noodsaaklik in die voorkoming van stagnasie en, onvermydelik, sal sommige daarvan lei tot omstredenheid en hewige meningsverskille. Daarom is dit belangrik om 'n samelewing van so vroeg of jonk as moontlik te begin toerus met leesvaardighede soos die verstaan van die werking van teksinterne korrektiewe in jeugverhale - 'n vertelstrategie waarin negatiewe waardes deur omkering, verandering of aanpassing kan bydra tot die sigbaar word van die eintlike, bedoelde positiewe waardes in verhale.

\section{Geraadpleegde bronne}

BARKER, C. 1999. Television, globalization and cultural identities. Philadelphia: Open University Press.

DU PLOOY, H.J.G. 1993. Die onontwykbare eie verhaal: De aanslag van Harry Mulisch en Die jakkalsjagter van Alexander Strachan as metaverhale. Stilet, 5(1):49-63, Maart.

DU PLOOY, H.J.G. 2001. Inleiding tot die studie van Afrikaanse en Nederlandse kortverhale. Potchefstroom: $\mathrm{PU}$ vir $\mathrm{CHO}$. 
DUGARD, J. 1980. Censorship in South Africa: the legal framework. (In Gordimer, N. What happened to Burger's daughter or how South African censorship works. Johannesburg: Taurus. p. 67-73.)

FRITZ, M.J. 2007. Die representasie van omstrede kwessies in kontemporêre Afrikaanse jeugverhale. Potchefstroom: Noordwes-Universiteit. (M.A.HAT verhandeling.)

\section{kyk VERKLARENDE HANDWOORDEBOEK VAN DIE AFRIKAANSE TAAL}

HOUGH, B. 2002. Skilpoppe. Kaapstad: Tafelberg.

LE ROUX, M. 1998. Jeug kry drie wenboeke. Die Burger: 16, 18 Nov.

MÜLLER, M. 1992. Postmodernisme. (In Cloete T.T., red. Literêre terme en teorieë. Pretoria: HAUM-Literêr. p. 397-400.)

NIEUWOUDT, S. 1998. Russiese poppe inspireer Hough om wenner te skryf. Beeld Plus: 5, 29 Sept.

RYAN, M. 1993. In search of the narrative theme. (In Sollors, W., ed. The return of thematic criticism. Cambridge: Harvard University Press. p. 321.)

STEENBERG, E. 1988. Primêre behoeftes van tieners waarin hul boeke voorsien. Klasgids, 23(2):14-19, Mei.

SUTHERLAND, Z. 1977. Children and books. 5th ed. Glenview: Scott, Foresman.

VAN DER WALT, B.J. 1992. Venster op die werklikheid: 'n reformatoriese lewensvisie-filosofie-wetenskap. Potchefstroom: $\mathrm{PU}$ vir $\mathrm{CHO}$.

VAN DER WESTHUIZEN, B. 1990. Sensuur, taal, kultuur en denke. Potchefstroom. (Ongepubliseerde lesings: Afrikaans vir Regstudente.)

VAN DER WESTHUIZEN, B. 2005. Barrie Hough. (In Wybenga, G. \& Snyman, M., reds. Van Patrys-hulle tot Hanna Hoekom: 'n gids tot die Afrikaanse kinder- en jeugboek. Pretoria: LAPA Uitgewers. p. 273-277.)

VAN RENSBURG, F.I.J. 1985. Pornografie. Durban: Butterworth.

VERKLARENDE HANDWOORDEBOEK VAN DIE AFRIKAANSE TAAL. 2000. Midrand: Perskor.

WEST, M.I. 2004. Censorship. (In Hunt, P., ed. 2004. International companion encyclopedia of children's literature. 2nd ed. Oxon: Routledge. p. 680689.)

Kernbegrippe:

Hough, Barrie: Skilpoppe

geweld

godsdiens

omstrede kwessies

politiek

seksualiteit

teksinterne korrektief 


\section{Key concepts:}

controversial issues

Hough, Barrie: Skilpoppe

politics

religion

sexuality

text internal corrective

violence 